\title{
Cloning of oestrogen receptor beta from Old and New World primates: identification of splice variants and functional analysis
}

\author{
Jayne E Sierens, Graeme A Scobie, Julie Wilson and Philippa T K Saunders \\ MRC Human Reproductive Sciences Unit, Centre for Reproductive Biology, The Chancellor's Building, 49 Little France Crescent, Edinburgh \\ EH16 4SB, UK \\ (Requests for offprints should be addressed to P Saunders; Email: p.saunders@ed.ac.uk)
}

\begin{abstract}
Oestrogens have a major impact on reproductive function in both males and females. Two oestrogen receptor genes known as $E R \alpha(E S R 1 N R 3 A 1)$ and $E R \beta$ (ESR2NR3A2) have been cloned. Splice variant isoforms of the ER $\beta$ gene have been identified in human, bovine and rodents and it has been suggested that the existence of these forms can influence oestrogen responsiveness. In the human, splicing of an alternative eighth exon results in the formation of a C-terminal variant called $h E R \beta c x$, or $h E R \beta 2$, but this isoform has not been identified in other species. The aim of the present study was to clone ER $\beta$ cDNAs from primates so as to determine how closely they resembled the ER $\beta$ isoforms found in the human. The two species studied were the stump-tailed macaque (Macaca arctoides), an Old World primate, and the common marmoset (Callithrix jacchus jacchus), a New World primate.

Full length ER $\beta$ (wild type, ER $\beta 1$ ) cDNAs were cloned from macaque and marmoset; they encoded proteins of similar size to those found in human ( 59 and $54 \mathrm{kDa}$, long and short forms respectively) and shared significant sequence homology $(97.5 \%$ in macaque and $93.8 \%$ in marmoset) with the human peptide sequence. Full length cDNAs homologous to the hER $\beta 2$ variant were identified in both primates. Marmoset ER $\beta 2$ was slightly shorter than that of human ER $\beta 2(54 \mathrm{kDa}$ compared with $55 \mathrm{kDa})$ and did not contain the peptide sequence used to raise an anti-hER $\beta 2$ antibody. All the macaque ER $\beta 2$ cDNAs contained $56 \mathrm{bp}$ of intronic sequence which included an in-frame stop codon resulting in translation of a truncated protein $(\sim 35 \mathrm{kDa})$. In all three species, truncated, alternatively spliced mRNAs lacking exon 5 were isolated on multiple occasions from all tissue extracts. In transient transfection assays, ER $\beta 2$-containing constructs were unable to induce transcription of an oestrogen response element (ERE) reporter plasmid in the presence of oestradiol. ER $\beta 1$ from human, macaque and marmoset exhibited minor differences in their ability to induce transcription of the ERE reporter when incubated with different ligands (oestradiol, PPT, DPN, 5-alpha-androstane-3-beta, 17 $\beta$-diol (3ßAdiol), genistein) and this may be due to amino acid substitutions within their ligand binding domains.

In conclusion, we have identified and cloned wild type ER $\beta$ (ER $\beta 1)$ from macaque and marmoset and demonstrated that splice variant mRNAs homologous to $h E R \beta 2$ are formed in both species. The marmoset monkey, therefore, provides a suitable animal model in which to investigate the impact of ER $\beta$ variant expression on tissue responsiveness to oestrogens.
\end{abstract}

Journal of Molecular Endocrinology (2004) 32, 703-718

\section{Introduction}

Oestrogen action is mediated via specific receptors (ER). The first oestrogen receptor was cloned from a human breast cancer cell line in 1986 (Green et al. 1986). In 1996, a second ER was cloned from rat (Kuiper et al. 1996) and human (Mosselman et al.
1996) tissues. The two receptors are known as oestrogen receptor alpha $(\mathrm{ER} \alpha$, ESR $1 \mathrm{NR} 3 \mathrm{Al})$ and oestrogen receptor beta (ER $\beta$, ESR2NR3A2) respectively. Evolutionary studies have suggested that the vertebrate steroid receptors evolved from an ancestral receptor with oestrogen receptor-like function by serial genome expansion (Thornton 
2001, Thornton et al. 2003). Human (h) ER $\alpha$ and hER $\beta$ contain significant sequence homology and are classified as subgroup A of the nuclear receptor subfamily 3 (Nuclear Receptors Nomenclature Committee 1999). They are the products of two genes located on different chromosomes (Enmark et al. 1997) and phylogenetic analysis suggests that they arose from a single duplication event at least 450 million years ago (Kelley \& Thackray 1999).

$\mathrm{ER} \alpha$ and $\operatorname{ER} \beta$ both bind to a range of oestrogenic ligands although they exhibit different affinities for some ligands notably genistein, raloxifene and tamoxifen (Kuiper et al. 1997, Barkhem et al. 1998). Key domains within ER $\alpha$ and $\mathrm{ER} \beta$ include the DNA binding domain $(\mathrm{C})$ and two transactivation domains (AF-1 and $\mathrm{AF}-2)$ located in the $\mathrm{N}$ (A/B domain) and $\mathrm{C}$ terminal (E/F domain) portions of the protein respectively (see reviews by Saunders 1998 and Nilsson et al. 2001). The crystal structures of the ligand binding domains of ER $\alpha$ and $\operatorname{ER} \beta$ have been determined and their overall arrangement shown to be similar, both containing 12 helices (Pike et al. 1999). In vitro studies have demonstrated that homodimers $(\mathrm{ER} \alpha-\mathrm{ER} \alpha$ or $\mathrm{ER} \beta-\mathrm{ER} \beta)$, or heterodimers $(\mathrm{ER} \alpha-\mathrm{ER} \beta)$, can be formed when both isoforms are expressed in the same cell (Cowley et al. 1997, Pettersson et al. 1997). Results obtained from in vitro and in vivo studies have suggested that one role played by $\operatorname{ER} \beta$ may be to modulate $\mathrm{ER} \alpha$-mediated transcriptional activity (Hall \& McDonnell 1999, Weihua et al. 2000).

Splice variant isoforms of the ER $\beta$ gene have been identified in a number of species including the human $(\mathrm{Lu}$ et al. 1998, Moore et al. 1998, Ogawa et al. 1998b, Inoue et al. 2000), the bovine (Walther et al. 1999) and rodents (Chu \& Fuller 1997, Lu et al. 1998, 2000). One striking feature revealed by sequencing of these products is that the variant most commonly found in rodent tissues, formed by an insertion of 18 amino acids within the ligand binding domain (Chu \& Fuller 1997, Pettersson et al. 1997), has not been detected in human tissue extracts (Chu et al. 2000; authors' unpublished observations). Furthermore, the extensive splicing of alternative exons at the $3^{\prime}$ end of the human $\operatorname{ER} \beta$ gene which results in formation of a number of $\mathrm{C}$-terminal variants (Moore et al. 1998) has not been reported for other species.

We have previously examined the expression of ER $\beta$ proteins using a polyclonal antibody directed against the hinge (D) domain of hER $\beta$ as well as monoclonal antibodies specific for hER $\beta$ wild type protein $(\mathrm{ER} \beta 1)$ and two of the hER $\beta \mathrm{C}$-terminal splice variants $(\mathrm{ER} \beta 2$, also know as $\mathrm{ER} \beta \mathrm{cx}$, and ERß4 (Moore et al. 1998, Ogawa et al. 1998b)). In human tissues immunopositive staining of cell nuclei has been reported using all these antibodies (Saunders et al. 2000, 2001, 2002a, Critchley et al. 2002, Scobie et al. 2002). In addition using the polyclonal antibody, ER $\beta$ protein has also been detected in tissues from a wide range of species including primates and rodents (Saunders et al. 2000, 2001, Nie et al. 2002, Zhou et al. 2002). Western blot analysis has shown that this antibody will bind to both hER $\beta 1$ and hER $\beta 2$ recombinant proteins. Immunohistochemistry using the monoclonal antibody specific for the $\mathrm{C}$-terminus of hER $\beta 1$ results in detection of $\operatorname{ER} \beta$ protein in granulosa cells of the primate ovary (Saunders et al. 2000) but we have not previously investigated whether an ER $\beta 2$ variant protein is expressed in the primates.

The aim of this study was to determine whether $\mathrm{ER} \beta$ splice variant isoforms which resemble those of the human exist in closely related mammalian species. We therefore cloned $\operatorname{ER} \beta$ cDNAs from two primates, namely the stump-tailed macaque (Macaca arctoides), an Old World primate, and the common marmoset (Callithrix jacchus jacchus), a New World primate, estimated to have diverged from the human line $\sim 25-27$ and $\sim 30-35$ million years ago respectively.

\section{Materials and methods}

\section{Human and primate tissues}

Marmoset tissues were collected from adult captive bred animals $(n=5)$ maintained in a colony that has been closed since 1973. Testes with epididymes attached were also obtained from three adult stump-tailed macaques that were being surgically castrated under general anaesthesia for colony management purposes. These samples were the same as those used in previous studies (Saunders et al. 2001). Additional blocks of fixed tissues were from an archive held at the Human Reproductive Sciences Unit. Sections of human endometrium were a gift from Professor Hilary Critchley (University of Edinburgh). 
Table 1 Primers sequences used for the isolation and sequencing of cDNAs containing the entire open reading frame of $h E R \beta 1$ and ER $\beta 2$

\begin{tabular}{|c|c|c|c|}
\hline & $5^{\prime}$-sense & 3'-antisense & $\begin{array}{l}\text { Size } \\
\text { (bp) }\end{array}$ \\
\hline \multicolumn{4}{|l|}{ Name } \\
\hline ER $\beta 1 \mathrm{~L}$ & CCACGAATCTTTGAGAACATTAT & GTGGGCCAGTTCACCTCAGG & 1698 \\
\hline $\mathrm{ER} \beta 2 \mathrm{~L}$ & CCACGAATCTTTGAGAACATTAT & GTGAAAATGTTACCCAAGAT & 1316 \\
\hline GAPDH & GAACGGGAAGCTCACTGGCAT & GTCCACCACCCTGTTGCTGTAG & 301 \\
\hline 100AS & & GCTATAGAATGTCATGGCTGGA & seq \\
\hline Seq1 & ATGAATTACAGCATTCCCAGCA & & seq \\
\hline Seq2 & TATGGAGTCTGGTCGTGTGA & & seq \\
\hline Seq3 & GTGAAGTGTGGCTCCCGGAG & & seq \\
\hline Seq4 & TTTGTGGAGCTCAGCCTGTT & & seq \\
\hline
\end{tabular}

\section{Immunohistochemistry}

Antibodies directed against $\mathrm{C}$-terminal peptides specific for hER $\beta 1$ and hER $\beta 2$ (hER $\beta c x$ ) were raised as described previously (Saunders et al. 2000, 2002a). The specificity of these antibodies has been validated using Western blotting with recombinant proteins and tissue extracts (Critchley et al. 2002, Saunders et al. 2002a). Immunohistochemistry was performed according to standard procedures described previously in detail (Saunders et al. 2000, 2001, 2002a). Briefly, all sections were subjected to heat-induced antigen retrieval. Anti-hER $\beta 1$ (clone PPG5/10, code MCA1974S; Serotec, Oxford, UK) was diluted 1:100 and anti-ER $\beta 2$ (clone 57/3) was diluted 1:40 in NRS/TBS/BSA. Sections were incubated with the primary antibody overnight at $4{ }^{\circ} \mathrm{C}$, washed with TBS and incubated with the secondary antibody (rabbit anti-mouse, Dako, Ely, Cambs, $\mathrm{UK}$ ) diluted 1:500 in NRS/TBS/BSA for $1 \mathrm{~h}$ at room temperature. Following washes in TBS, sections were incubated with avidin-biotin-horseradish peroxidase linked complex (Dako,) and bound antibodies were visualised using 3,3'-diaminobenzidine tetrahydrochloride (DAB, Dako). Images were captured using an Olympus Provis microscope (Olympus Optical Co, London, UK) equipped with a Kodak DCS330 camera (Eastman Kodak Co., Rochester, NY, USA) and assembled using Photoshop 6 (Adobe, Mountain View, CA, USA).

\section{Synthesis of complementary cDNAs}

Frozen tissue samples (ovary, testis or epididymis) were ground up under liquid nitrogen using a pestle and mortar, divided into approximately
$50 \mathrm{mg}$ samples, and stored at $-70{ }^{\circ} \mathrm{C}$. RNA was extracted using Tri Reagent (Sigma, Poole, Dorset, UK) according to the manufacturer's instructions, dissolved in RNAse-free water, and $5 \mu \mathrm{g}$ total RNA were subjected to reverse transcription using Expand Reverse Transcriptase (Roche, Lewes, East Sussex, UK) and an oligo dT primer. cDNAs were purified by heating to $100{ }^{\circ} \mathrm{C}$ for $5 \mathrm{~min}$, followed by RNase treatment at $37^{\circ} \mathrm{C}$ for $15 \mathrm{~min}$ and finally by passing through a High Pure PGR Purification column (Roche) and were quantified on a Pharmacia Biotech Genequant (St Albans, Herts, UK). All samples were adjusted to a final concentration of $5 \mathrm{ng} / \mu \mathrm{l}$ in TE buffer $(10 \mathrm{mM}$ Tris/HCl pH 7·5, 1 mM EDTA).

\section{Screening of cDNAs using primers specific for the C terminus of ERß1 and ERß2}

Complementary DNAs prepared from human, macaque and marmoset tissues were used in PGR reactions containing AGS Gold Taq (Hybaid, Ashford, Middlesex, UK). The sense primer which was located in exon 7 (hER $\beta \mathrm{s} ; 5^{\prime}$ GGCATCTTCGTCCCAGCAGCA) annealed to both hER $\beta 1$ (AB006590 starting at position 1432) and hER $\beta \mathrm{cx} / 2$ (AB006589 starting at position 2608). This primer was used in conjunction with one of two antisense primers which were specific for hER $\beta 1$ (antisense strand, 5'-CACT GAGACTGTGGGTTCTGGGA, ends at 1691, expected size $259 \mathrm{bp}$ ) and hER $\beta 2$ (antisense strand, 5'-CACTGCTCGATCGTTGGTTC, ends at 2762, expected size 155 bp). Control reactions to ensure that intact cDNA was present contained 
primers directed against glyceraldehyde-3phosphate dehydrogenase (GAPDH) (Table 1). PCR conditions were as follows: 1 cycle of $94{ }^{\circ} \mathrm{C}$ for $2 \mathrm{~min}$ followed by 30 cycles of $94{ }^{\circ} \mathrm{C}$ for $30 \mathrm{~s}$, $58{ }^{\circ} \mathrm{C}$ for $30 \mathrm{~s}$ and $72{ }^{\circ} \mathrm{C}$ for $30 \mathrm{~s}$, with a final cycle of $72{ }^{\circ} \mathrm{C}$ for $10 \mathrm{~min}$.

\section{Amplification of full length ERß1 and ERß2 cDNAs}

Full length cDNAs were amplified from cDNA pools using primers homologous to human ER $\beta$ sequences $5^{\prime}$ of the ATG start (sense) and 3' of the TGA stop (antisense). Primer pairs (designated as ER $\beta 1 \mathrm{~L}$ and ER $\beta 2 \mathrm{~L}$ ) are given in Table 1. PGR conditions were the same as those used above except that the annealing temperature was reduced to $55^{\circ} \mathrm{C}$ and the extension time increased to $1 \mathrm{~min}$ $30 \mathrm{~s}$. PCR products were purified through a Clontech 400 column (BD Biosciences, Cowley, Oxon, UK) and directly sequenced using the primers used for PCR amplification as well as internal sequencing primers homologous to hER $\beta$ (Table 1). To control for introduction of sequence changes from PCR amplification, the reactions were conducted several times on cDNAs prepared from more than one tissue on more than one occasion; a consensus sequence was determined by multiple alignment.

\section{Preparation of ERß1/ERß2 expression constructs}

ER $\beta 1$ and ER $\beta 2$ cDNAs generated from all three species using the 'long' primer pair were cloned into the TA cloning site of the eukaryotic expression vector pCDNA3·1/V5-His (Invitrogen, Paisley, Strathclyde, UK) according to the manufacturer's instructions. This plasmid was chosen because it contains a T7 RNA polymerase site upstream of the insertion site and can therefore be used for in vitro synthesis of proteins. The plasmids were sequenced fully and purified using caesium chloride according to standard methods.

\section{Transcription/translation analysis of cloned cDNAs (TNT)}

Purified pCDNA $3 \cdot 1$ plasmids $(1 \mu \mathrm{g}$ each) were added to separate tubes containing $50 \mu \mathrm{l}$ T7 coupled reticulocyte lysate (TNT, Promega,
Southampton, UK) in the presence of $20 \mu \mathrm{Ci}$ ${ }^{35}$ S-methionine (Amersham, Little Chalfont, Bucks, UK). Transcription coupled translation was allowed to proceed for $90 \mathrm{~min}$ at $30^{\circ} \mathrm{C}$. Expressed proteins $(2 \cdot 5 \mu \mathrm{l}$ of each lysate) were separated on a 4-20\% denaturing gradient gel (Invitrogen) and visualised by direct exposure of the gel to X-ray film (XLS, Kodak).

\section{Oestrogenic ligands}

17ß-Oestradiol (E-8875), 5-alpha-androstane-3beta, 17ß-diol (Adiol; A-7630) and 4',5,7trihydroxyisoflavone (Genistein; G-6649) were all purchased from Sigma. DPN and PPT were purchased from Tocris Cookson Ltd (Avonmouth, Bristol, UK). DPN (2,3-bis(4-hydroxyphenyl)propionitrile) is marketed as an $\operatorname{ER} \beta$ agonist with a 70-fold selectivity over ER $\alpha$ (Meyers et al. 2001). PPT (4,4',4"-(4-propyl-[1H]-pyrazole-1,3,5-triyl) trisphenol) is marketed as an ER $\alpha$ agonist and is reported to exhibit 410-fold selectivity for ER $\alpha$ over ER $\beta$ (Stauffer et al. 2000). All ligands were reconstituted in ethanol $(100 \% \mathrm{v} / \mathrm{v})$ apart from genistein which was dissolved in DMSO; all stocks were stored at $-20{ }^{\circ} \mathrm{C}$.

\section{Transient transfections}

Hep G2 cells (human hepatocellular carcinoma, ECACC; Health Protection Agency, Porton Down, UK) were maintained in DMEM phenol red-free medium (Sigma) supplemented with 10\% charcoalstripped fetal bovine serum (GIBCO, Paisley, Strathclyde, UK), D-glucose (Sigma), L-glutamate (Sigma), non-essential amino acids (Ambion, Abingdon, Oxon, UK), fungizone (GIBCO) and penicillin-streptomycin (Sigma). Cells were plated out into 12-well plates (Corning, Fisher Scientific, Loughborough, Leics, UK) at a density of $1 \times 10^{5}$ cells per $\mathrm{ml}$ media $24 \mathrm{~h}$ prior to transfection. Human ER $\alpha$ was obtained as a full length cDNA in a PIC OH plasmid (ATCG, LGC Promochem, Teddington, Middx, UK) and subcloned into pcDNA3 1 using BamHI and EcoRV restriction sites. ER $\beta 1$ and ER $\beta 2$ expression vectors were prepared as above. A reporter construct containing $3 \times$ vitellogenin oestrogen response element (ERE)linked to TK-luciferase was a kind gift from S C Nagel and D P McDonnell (Hall \& McDonnell 1999). In each well, cells were co-transfected with 
$1 \mu \mathrm{g}$ ER, $0.5 \mu \mathrm{g} 3 \times$ ERE-luciferase reporter and $100 \mathrm{ng}$ Renilla cytomegalovirus (GMV) internal control; to introduce the DNA into the cells they were incubated for $4 \mathrm{~h}$ with JetPEI transfection reagent (Cambridge Biosciences, Cambridge, Cambs, UK) and the DNA mix. Ligands or vehicle (ethanol) were added and cells were incubated for a further $24 \mathrm{~h}$ before the medium was replaced with fresh medium containing the appropriate ligand for a further $24 \mathrm{~h}$. Cells were harvested and assayed using a luciferase assay kit from Promega. Results were normalised against the Renilla internal control, and the amount of luciferase activity obtained in the absence of ligand (ethanol alone) was designated as 1; all results were expressed as a fold increase relative to the value obtained in the ligand-free control present in each experiment. All treatments were performed in duplicate wells and experiments repeated at least 3 times. Results are presented as the mean \pm S.D. of the fold changes seen in the individual experiments.

\section{Results}

\section{Detection of ERß1 and ERß2 mRNAs in samples from multiple human and primate tissues}

RT-PGR analysis using hER $\beta 1$ - and hER $\beta 2$ specific primer pairs resulted in amplification of DNA from ovaries, testes and epididymes from marmoset and from testes and epididymes from macaque (Fig. 1). The sizes of the amplified DNAs were identical to those from human ovaries and testes which were used as positive controls (Fig. 1); no reaction product was seen in negative control samples lacking cDNA. In a more extensive comparison of tissues from human and marmoset the pattern of expression of mRNAs was identical in both species: ER $\beta 1$ and ER $\beta 2$ (heart, ovary, testis), ER $\beta 1$ alone (brain, liver, placenta), neither transcript (kidney). Preliminary sequence analysis confirmed that the DNA fragments from marmoset and macaque were homologous to $\operatorname{hER} \beta 1$ and hER $\beta 2$ (not shown).

\section{Immunohistochemistry using hERß1- and hERß2-specific monoclonal antibodies}

Consistent with the identification of ER $\beta 1$ mRNAs in primate tissue extracts and with previous
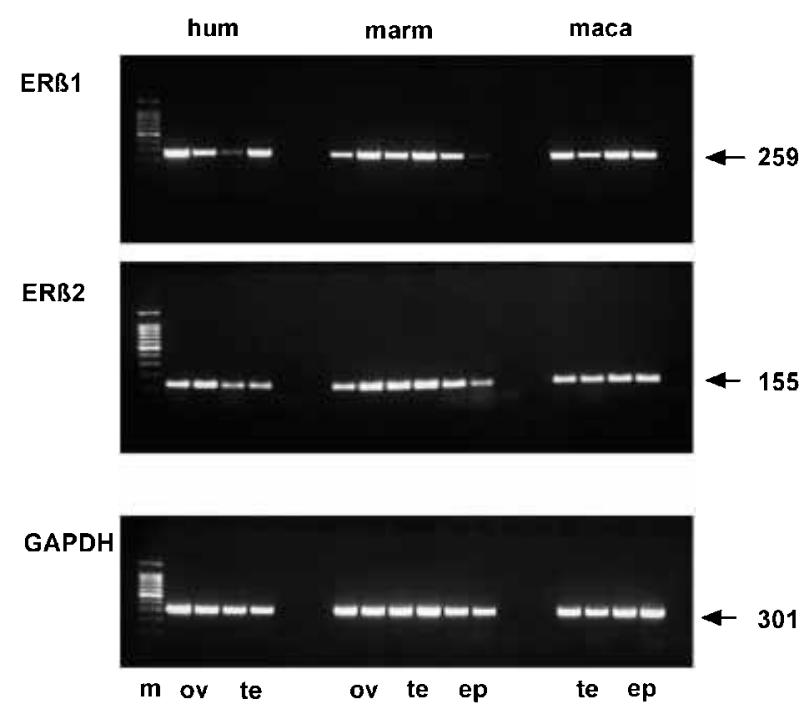

Figure 1 Detection of ER $\beta 1$ and ER $\beta 2$ mRNAs in cDNAs prepared from human, marmoset and macaque tissues. RT-PCR analysis of reproductive tissues from human (hum), marmoset (marm) and macaque (maca). Using sequence-specific primers DNA fragments of the size predicted for ER $\beta 1$ (top panel, $259 \mathrm{bp}$ ) and ER $\beta 2$ (middle panel, $155 \mathrm{bp}$ ) were identified in macaque testes (te) and epididymes (ep) as well as in ovaries (ov), testes (te) and epididymes (ep) from the marmoset. The fragments were of an identical size to those in control human tissues (ovary, testes). All samples were positive for the GAPDH control (lower panel, $301 \mathrm{bp}$ ). m, molecular weight marker.

immunohistochemical data (Saunders et al. 2000), $\mathrm{ER} \beta 1$ protein was immunolocalised to endometrium (Fig. 2a-c) and testes (Fig. 2g-i) from human, macaque and marmoset using a monoclonal antibody specific for the C-terminus of hER $\beta 1$. However, when staining reactions were undertaken on the same tissue panel using an hER $\beta 2$-specific antibody, staining was only detected in human tissues (Fig. 2d, j) and no immunopositive reaction was detected in any of the primate tissues examined (Fig. 2e, f, k, i, and unpublished observations).

\section{Sequence analysis of full length cDNAs encoding ERß1 and ERß2 variants in macaque and marmoset}

Double stranded DNA of the expected sizes were amplified from macaque and marmoset cDNA pools using primers located upstream of the ATG in human ER $\beta$ and downstream of the stop site 


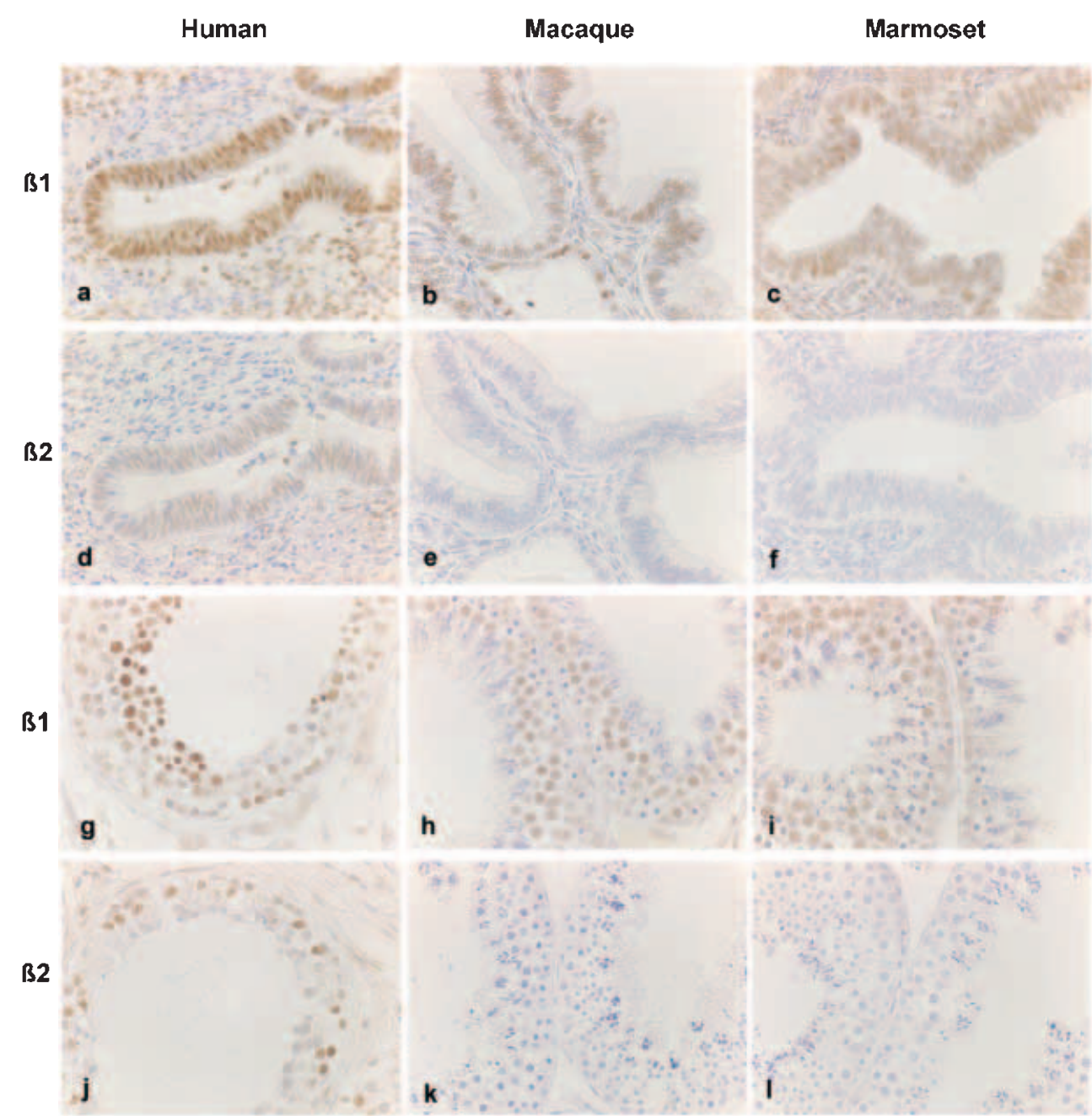

Figure 2 Immunohistochemical evaluation of ER $\beta 1$ and ER $\beta 2$ expression in endometrium and testes from human, macaque and marmoset using variant-specific monoclonal antibodies. Sections from human (a, d, g, j), macaque (b, e, h, k) and marmoset (c, f, i, l) were stained with hER $\beta 1$ - or hER $\beta 2$-specific monoclonal antibodies. Positive staining of cell nuclei was observed for ER $\beta 1$ in endometrium $(a-c)$ and testes $(g-i)$ from all three species. However when the same tissues were stained for ER $\beta 2$ only human endometrium (d) and testis (j) were immunopositive.

in either $\mathrm{hER} \beta 1$ or $\mathrm{hER} \beta 2 / \beta \mathrm{cx}$ (accession no. NM_001437). The nucleotide sequences obtained have been lodged in Genbank (accession nos Y09372, AF393816, AF393815).

The peptide sequences predicted from the open reading frames of the ER $\beta 1 \mathrm{cDNAs}$ from macaque and marmoset are compared in Fig. 3A. Note that there is a high degree of sequence conservation with $97 \cdot 5 \%$ (517/530) homology between macaque and human and 93.8\% (497/530) homology between marmoset and human. In two positions (amino acids 341 and 478) identical amino acid substitutions were present in macaque and marmoset but all other changes were different in the two species. The sequence homology within the peptide used to raise the ER $\beta 1$-specific monoclonal antibody (underlined at the C-terminus of hER $\beta 1$ ) was 18/19 and 17/19 for macaque and marmoset respectively compared with human.

A full length protein of 486 amino acids was predicted from the open reading frame $(\mathrm{ORF})$ of the marmoset ER $\beta 2$ cDNA (C-terminal portion 
of protein illustrated in Fig. 3B). Comparison with human ER $\beta 2$ showed $91 \cdot 1 \%$ amino acid conservation (451/495); however the protein was slightly shorter than the human protein and the peptide sequence used to raise the human ER $\beta 2$-specific monoclonal (underlined in Fig. 3B) was not conserved in the marmoset. Although a cDNA of comparable size to hER $\beta 2$ was amplified from macaque cDNA pools, sequence analysis revealed that it included an additional $56 \mathrm{bp}$ of sequence which was homologous to sequences at the $5^{\prime}$ end of intron 4 in the human $\operatorname{ER} \beta$ gene sequence. The inclusion of this intronic sequence resulted in the introduction of an in-frame stop codon resulting in a predicted ORF of 321 amino acids. Extensive analysis of multiple clones from several macaque tissues did not result in isolation of any cDNAs lacking this intronic sequence.

\section{Analysis of recombinant proteins prepared by in vitro translation}

Proteins corresponding to both the long $(59 \mathrm{kDa}$, Ogawa et al. 1998a) and short (54 kDa, (Mosselman et al. 1996) forms of hER $\beta 1$ were translated from the human cDNAs (Fig. 4 lane 1) consistent with Western data showing that both AUG start sites are functional in vivo (Saunders et al. 2002b). Plasmids containing ER $\beta 1$ cDNAs isolated from marmoset and macaque generated proteins of a similar size to hER $\beta 1$ (Fig. 4 lanes 3, 5, 6). Proteins synthesised from hER $\beta 2$-containing plasmids were smaller $(\sim 55.5 \mathrm{kDa}$ and $\sim 50.5 \mathrm{kDa})$ than those of hER $\beta 1$, consistent with the use of alternative AUG starts and the incorporation of an alternative terminal coding exon with a shorter ORF than that of hER $\beta 1$. Translation of ER $\beta 2$ cDNAs from marmoset and macaque resulted in synthesis of proteins of $54 \cdot 3 \mathrm{kDa}$ (lane 4) and $35 \cdot 8 \mathrm{kDa}$ (lanes 7 and 8$)$ respectively. In macaque, a second prominent protein band was detected at $30 \mathrm{kDa}$ and this would be consistent with the use of the alternative AUG resulting in a protein lacking 54 amino acids at the amino terminus.

\section{Reporter gene activation in transient transfection assays}

Incubation of cells co-transfected with an ERE reporter and hER $\alpha$ or $\mathrm{hER} \beta 1$ (wild type, WT) with increasing concentrations of oestradiol (Fig. 5) resulted in a ligand-dependent induction of reporter gene expression. Consistent with previous reports, $\mathrm{ER} \alpha$ was able to induce four- to fivefold higher levels of reporter gene expression than ER $\beta 1$ at equivalent ligand concentrations (Table 2). Activation of the reporter gene by ER $\beta 1$-containing constructs was similar for human, macaque and marmoset (Fig. 5), although the marmoset ER $\beta 1$ was slightly more active than its human homologue at higher concentrations of oestradiol $\left(10^{-7}\right.$, $\left.10^{-6} \mathrm{M}\right)$. Consistent with the absence of a functional AF-2 domain in $\operatorname{hER} \beta 2$, the protein did not activate ERE-luciferase reporter gene expression in the presence of any of the ligands tested (e.g. oestradiol, Fig. 5 (hER $\beta 2$ )). When incubated with increasing concentrations of PPT, activation of the ERE reporter by the ER $\beta 1$-containing constructs (Fig. 6) was minimal compared with that observed using the hER $\alpha$-positive control (Fig. 6) and only the macaque ER $\beta 1$ showed any activity although this was approximately 12 -fold lower than hER $\alpha$ even at $10^{-6} \mathrm{M}$ ligand concentration (Table 2). DPN is marketed as an ER $\beta$ selective agonist and at concentrations between $10^{-9}$ and $10^{-7} \mathrm{M} \mathrm{ERE}$ reporter activation by human, macaque and marmoset ER $\beta 1$-containing constructs was greater than that seen with $\operatorname{hER} \alpha$ (Fig. 6). However, at higher concentrations of ligand (i.e. $10^{-6}$ to $\left.10^{-4} \mathrm{M}\right)$ DPN was able to act as a potent agonist for hER $\alpha$. Identical reporter gene activation assays were carried out in the presence of Adiol and genistein and the results obtained are compared with those from incubations with oestradiol, PPT and DPN in Table 2.

\section{Discussion}

The aim of the current study was to establish whether wild type and variant $\operatorname{ER} \beta$ proteins in primate species share significant sequence homology with those from the human. We have previously detected ER $\beta$ protein expression in tissues from these primate species using immunohistochemistry with an antibody directed against the hinge domain of human $\operatorname{ER} \beta$ (Saunders et al. 2000, 2001). A comparison of the ER $\beta 1$ and ER $\beta 2$ proteins identified in this study is presented in Fig. 7. It is notable that in both an Old World and a New World primate not only did the ER $\beta 1$ proteins share significant sequence homology with 
A

Contig\# 1 hERbeta 1 mac ERbeta 1 marm ERbeta 1

Contig\# 1 hERbeta 1 mac ERbeta 1 marm ERbeta 1

Contig\# 1 hERbeta 1 mac ERbeta 1 marm ERbeta 1

Contig\# 1 hERbeta 1 mac ERbeta 1 marm ERbeta 1

Contig\# 1 hERbeta 1 mac ERbeta 1 marm ERbeta 1

Contig\# 1 hERbeta 1 mac ERbeta 1 marm ERbeta 1

Contig\# 1 hERbeta 1 mac ERbeta 1 marm ERbeta 1

Contig\# 1 hERbeta 1 mac ERbeta 1 marm ERbeta 1

Contig\# 1 hERbeta 1 mac ERbeta 1 marm ERbeta 1

Contig\# 1 hERbeta 1 mac ERbeta 1 marm ERbeta 1

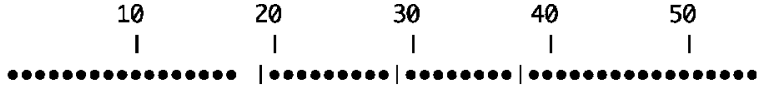

MDIKNSPSSLNSPSSYNCSQSILPLEHGSIYIPSSYVDSHHEYPAMTFYSPAVMN MDIKNSPSSLNSPSSYNCSQSILPLEHGSIYIPSSYVESHHEYPAMTFYSPAVMN MDIKNSPSSLNSPSSYNFGQSILPLEHGPIYIPSSYVESHHEYPAMTFYSPAVMN

\begin{tabular}{|c|c|c|c|c|}
\hline 60 & 70 & 80 & 90 & 100 \\
\hline I & 1 & I & 1 & 1 \\
\hline
\end{tabular}
YSIPSNVTNLEGGPGRQTTSPNVLWPTPGHLSPLVVHRQLSHLYAEPQKSPWCEA YSIPSNVTNLEGGPGRQTASPNVLWPTPGHLSPLAVHRQLSHLYAEPQKSPWCEA YSIPSSVTNLEEGPGRQITSPNMLWSTPGHLSPLAVHHQLSHLYAEPQKSPWCEA

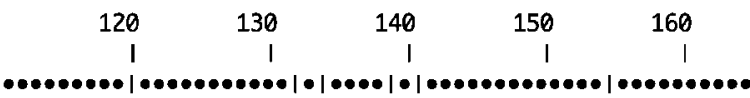
RSLEHTLPVNRETLKRKVSGNRCASPVTGPGSKRDAHFCAVCSDYASGYHYGVWS RSLEHTLPVNRETLKRKVSGNRCTSPVTSPSSKRDAHFCAVCSDFASGYHYGVWS RSLEHTLPVSRETLKRKVSGNHCASPVTGPSSKRDAHFCAVCSDYASGYHYGVWS

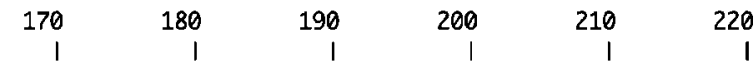
$\bullet \bullet \bullet \bullet \bullet \bullet \bullet \bullet \bullet \bullet \bullet \bullet \bullet \bullet \bullet \bullet \bullet \bullet \bullet \bullet \bullet \bullet \bullet \bullet \bullet \bullet \bullet \bullet \bullet \bullet \bullet \bullet \bullet \bullet \bullet \bullet \bullet \bullet \bullet \bullet \bullet \bullet \bullet \bullet \bullet \bullet \bullet$ CEGCKAFFKRSIQGHNDYICPATNOCTIDKNRRKSCQACRL RKCYEVGMVKCGSR CEGCKAFFKRSIQGHNDYICPATNQCTIDKNRRKSCQACRLRKCYEVGMVKCGSR CEGCKAFFKRSIQGHNDYICPATNQCTIDKNRRKSCQACRLRKCYEVGMVKCGSR

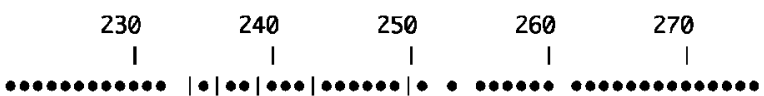
RERCGYRLVRRQRSADEQLHCAGKAKRSGGHAPRVRELLLDALSPEQLVLTLLEA RERCGYRLVRRORSADEOVHCASKAKRSGSHTPLVRELLLDALSPEOLVLTLLEA RERCGYRLVRRQGNAEEQLHCAGKAKRSGGHVPRVRELLLSALSPEQLVLTLLEA

$\begin{array}{rrrrrr}280 & 290 & 300 & 310 & 320 & 330 \\ 1 & 1 & 1 & \mid & 1 & 1\end{array}$
$\bullet \bullet \bullet \bullet \bullet \bullet \bullet \bullet \bullet \bullet \bullet \bullet \bullet \bullet \bullet \bullet \bullet \bullet \bullet \bullet \bullet \bullet \bullet \bullet \bullet \bullet \bullet \bullet \bullet \bullet \bullet \bullet \bullet \bullet \bullet \bullet \bullet \bullet \bullet \bullet \bullet \bullet \mid \bullet \bullet \bullet \bullet$ EPPHVLISRPSAPFTEASMMSLTKLADKELVHMISWAKKIPGFVELSLFDQVRL EPPHVLISRPSAPFTEASMMMSL TKLADKELVHMISWAKKIPGFVELSLFDQVRL EPPHVLISRPSVPFTEASMMMSL TKLADEEL VHMISWAKKIPGFVELSLLDQVRL

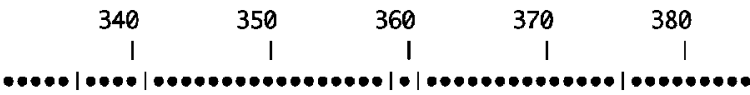
LESCWMEVLMMGLMWRSIDHPGKLIFAPDLVLDRDEGKCVEGILEIFDMLLATTS LESCWMEVLMVGLMWRSIDHPGKLIFAPDLVLDRDEGKCVEGILEIFDMLLATTS LESCWLEVLMVGLMWRSIDHPGKLIFAPNLILDRDEGKCVEGILEVFDMLLATTS

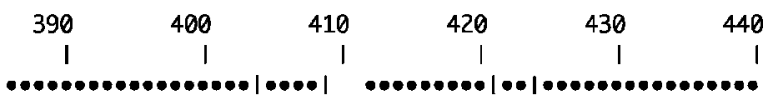
RFRELKLQHKEYLCVKAMILLNSSMYPLVTATQDADSSRKLAHLLNAVTDALVWN RFRELKLOHKEYLCVKAMILLNSNMYPLVTATODADSSRKLAHLLNAVTDALVWN RFRELKLQHKEYLCVKAMVLLNSQYDPLVTATQDAESSQKLAHLLNAVTDALVWN

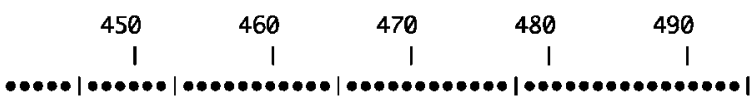
IAKSGISSQQQSMRLANLLMLLSHVRHASNKGMEHLLNMKCKNVVPVYDLLLEML IAKSGISSOOOSMRLANLLMLLSHVRHASNKGMEHLLSMKCKNVVPVYDLLLEML IAKSGFSSQQQSVRLANLLMLLSHIRHASNKGMEHLLSMKCKNVVPVYDLLLEMM

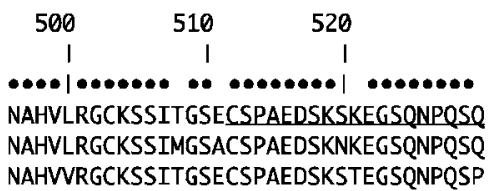




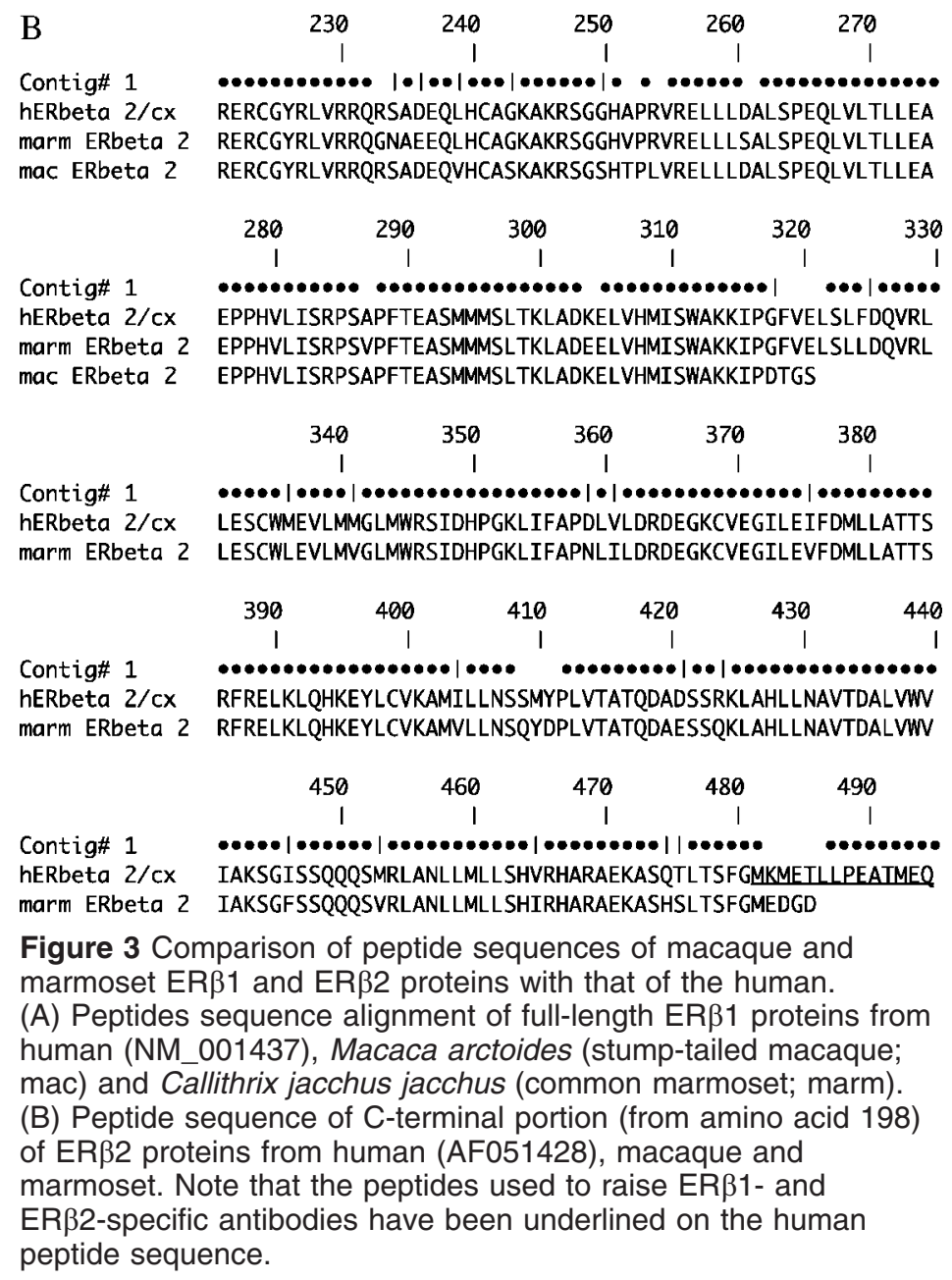

hER $\beta$, but variant mRNAs homologous to hER $\beta 2$ (also known as hER $\beta \mathrm{cx}$ ) were identified. This splice variant isoform has not previously been identified in other species and its existence in primates would suggest that the mechanisms that control the alternative splicing of the eighth coding exon of the $\mathrm{ER} \beta$ gene evolved at, or before, the divergence of the New World primates from the human line approximately 35 million years ago. We have not found any evidence in these, or other unpublished studies, for the existence of a variant equivalent to the rodent ER $\beta 2$ variant (Chu \& Fuller 1997, Petersen et al. 1998) in human or primate tissues, a finding in agreement with other investigators who have also failed to detect hER $\beta 2$ homologues in rodents (Chu et al. 2000). Further studies are needed to determine if the inclusion of intronic sequences such as those seen in the macaque are replicated in other species. Interestingly, studies on the organisation of spermatogenesis in primate species have revealed that the marmoset more closely resembles the human than does the macaque (Millar et al. 2000, Wistuba et al. 2003).

Sequence comparisons between the peptides predicted from the open reading frames of the ER $\beta 1$ and ER $\beta 2$ cDNAs from the macaque and marmoset with the hER $\beta 1$ and hER $\beta 2$ proteins solved the apparent conflict between results obtained with RT-PCR and immunohistochemistry. Although sequences homologous to the peptide used to raise the anti-hER $\beta 1$ monoclonal were identified in the ER $\beta 1$ sequences isolated from both primates, this was not the case when ER 32 protein sequences were analysed. In vitro transcription/translation revealed that in the primate species, as well as in the human, more than 


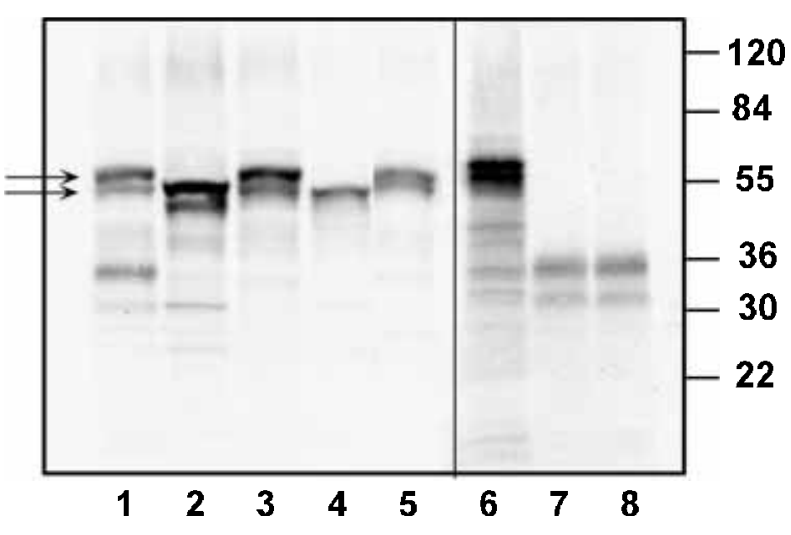

Figure 4 Analysis of proteins expressed in vitro from human, macaque and marmoset ER $\beta 1$ and ER $\beta 2$ cDNAs. Wells contained proteins synthesised from full length cDNAs by T7-coupled transcription/translation as follows: lane 1, hER $\beta 1$; lane 2, hER $\beta 2$; lane 3, marmoset ER $\beta 1$; lane 4, marmoset ER $\beta 2$; lane 5, macaque ER $\beta 1$; lane 6, macaque ER $\beta 1$; lanes 7 and 8, macaque ER $\beta 2$. Molecular weight markers were run in a parallel lane on all gels. Note that all proteins showed evidence of use of alternative ATG start sites within the cDNAs (e.g. arrows). Results from two separate gels are shown.

one size of protein was generated from the full length cDNAs and that their sizes were consistent with the use of two different AUG start sites as previously documented (Ogawa et al. 1998a, Tremblay et al. 1999). We have shown that ER $\beta 1$ proteins with sizes identical to long $(59 \mathrm{kDa})$ and short $(54 \mathrm{kDa})$ recombinant hER $\beta$ can be extracted from human breast cancers (Saunders et al. 2002b) consistent with induction of translation at both AUGs in vivo.

Inoue et al. (2000) cloned and sequenced a splice variant isoform of hER $\beta$ that lacked exon 5 and showed that this was able to act as a dominant negative inhibitor of ER $\alpha$ - and ER $\beta 1$-induced gene activation. We (Gritchley et al. 2002, Scobie et al. 2002; present study) and others (Speirs et al. 2000, Poola et al. 2002a) have reported the expression of exon 5-deleted mRNAs in normal and malignant tissues and cell lines. It is notable that the cDNA for the macaque ER $\beta 2$ contained a portion of intron 4 consistent with the activation of a cryptic splice site, suggesting that the exon 4 /intron 4 splice site is particularly susceptible to alternative splice site selection. Although multiple cDNA pools were analysed from several tissues we never identified a macaque ER $\beta 2$ cDNA that lacked this intronderived sequence. The macaque ER $\beta 2$ proteins generated in vitro from the cDNA clones migrated with apparent molecular masses of $\sim 35$ and $30 \mathrm{kDa}$ on acrylamide gels and it is notable that in previous studies using protein extracts from macaque tissues, proteins of similar size were identified on Western blots (see Fig. 4 in Saunders et al. 2001). Because the antibodies directed against hER $\beta 2$ did not cross-react with the ER $\beta 2$ proteins identified in either of the primates, a direct comparison between the pattern of expression of hER $\beta 2$ and primate ER $\beta 2$ proteins using Western analysis or immunohistochemistry will require development of new antibody reagents.

Functional studies were carried out using transient co-transfection of ER-containing constructs and a luciferase reporter gene driven by a promoter made up of three copies of the vitellogenin ERE. This reporter has been used extensively to investigate the ability of oestrogens to activate $\mathrm{ER} \alpha$ and $\mathrm{ER} \beta$ and is strongly induced by $\mathrm{ER} \alpha$ in the presence of a range of oestrogens and xenoestrogens (Hall \& McDonnell 1999, Hall \& Korach 2002). Consistent with previous reports (Ogawa et al. 1998b, Peng et al. 2003) ERß2containing constructs were unable to activate reporter gene expression in the presence of oestradiol. All the ER $\beta 2$ proteins identified lacked the core AF-2 domain (see Fig. 7), which is located in helix 12 of $\mathrm{ER} \alpha$ and ER $\beta 1$ (Tanenbaum et al. 1998), but contain sequences essential for dimerisation and DNA binding (Lees et al. 1990).

The functional significance of the expression of $\mathrm{ER} \beta 2$ and other $\operatorname{ER} \beta$ splice variants in human cell lines and tissues has been investigated in a number of ways. Using gel-shift analysis, Moore et al. (1998) demonstrated that ER $\beta 1$ (WT) and ER $\beta 2$ could form homo- and heterodimers. From transient co-transfection studies, there is evidence that hER $\beta 2$ can act as a dominant negative suppressor of oestrogen-activated hER $\alpha$-mediated gene activation in vitro (Ogawa et al. 1998b, Peng et al. 2003). $\mathrm{ER} \beta$ variant mRNAs have been detected in a range of malignant tissues including breast cancers (Poola et al. 2002b), and in support of the idea that ER $\beta 2$ may act as a dominant negative 'receptor' it has been reported that co-expression of $\operatorname{ER} \alpha$ and $\mathrm{ER} \beta 2$ is associated with reduced expression of progesterone receptor in breast cancer specimens (Saji et al. 2002). Our studies showing that the marmoset contains an ER $\beta$ splice variant with close homology to hER $\beta 2$ as well as an exon 5-deleted 

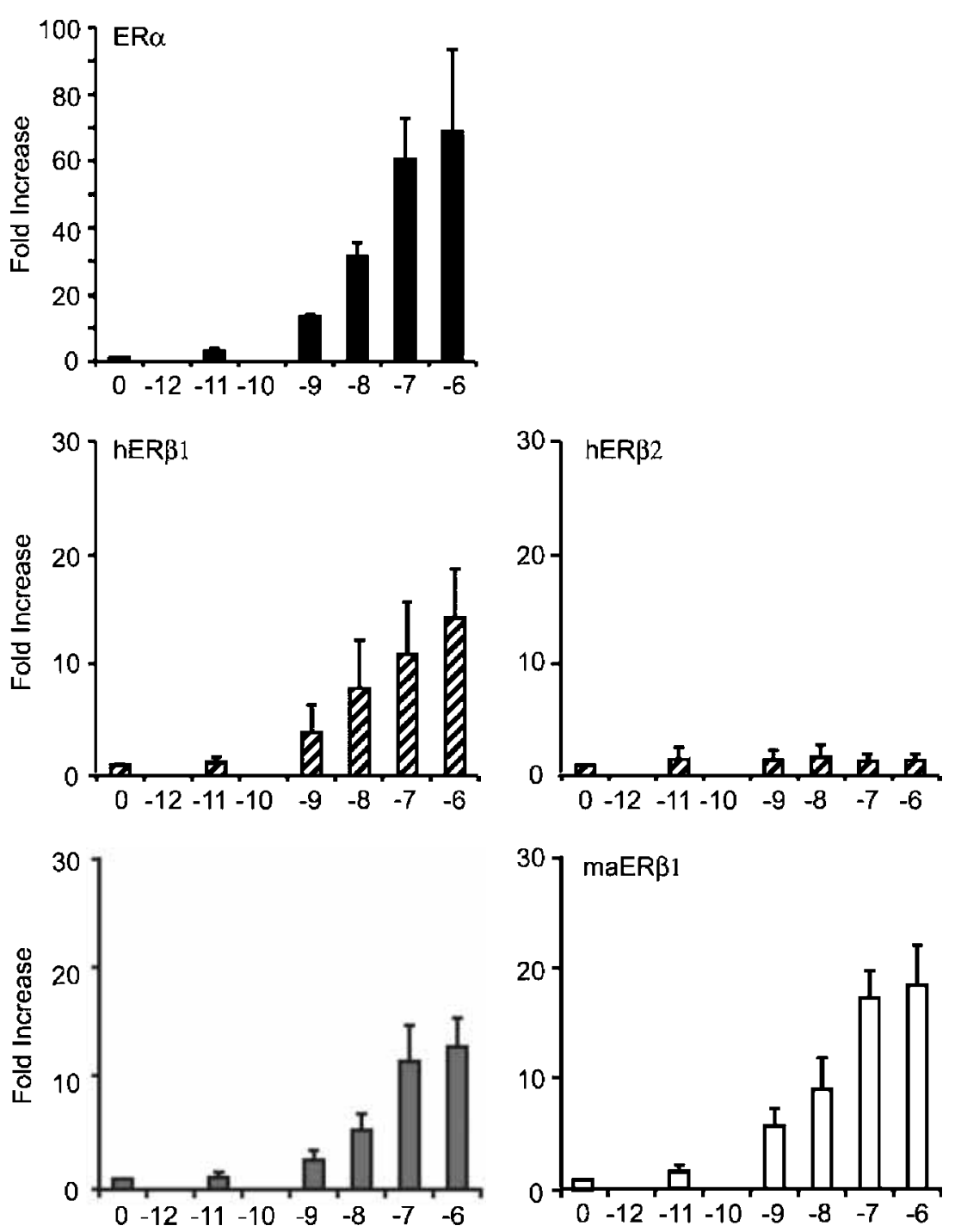

Steroid Concentration

Figure 5 Impact of oestradiol on the ability of ER expression constructs to activate an ERE-luciferase reporter. Panels show human ER $\alpha$ (note different vertical scale), hER $\beta 1, \mathrm{hER} \beta 2$, macaque ER $\beta 1$ (mcER $\beta 1$ ) and marmoset ER $\beta 1$ (maER $\beta 1$ ). Oestradiol was added to wells in the concentration range $10^{-12}$ to $10^{-6} \mathrm{M}$. All changes in induction of the ERE-luciferase reporter construct were corrected using an internal Renilla control. Fold differences are related to the level of reporter gene expression in the absence of ligand (0).

variant mRNA means this species may provide a suitable animal model in which to assess the impact of the expression of $\operatorname{ER} \beta$ variants on tissue responsiveness to oestrogens.

Detailed structural analysis of ER proteins bound to agonists and antagonists has provided clues as to the way(s) in which these ligands influence co-factor recruitment by altering the position adopted by helix 12 (Brzozowski et al. 1997, Shiau et al. 1998). Although amino acids corresponding to helix 12 in human ER $\beta$ (488 to 499) (Pike et al. 1999) are fully conserved in macaque $\mathrm{ER} \beta 1$, in the marmoset leucine 495 is changed to methionine. This amino acid is homologous to leucine 548 in mouse ER $\alpha$; mutation of this amino acid to alanine was shown by Mahfoudi et al. (1995) to alter the responsiveness 
Table 2 Results of transient transfection studies using a 3xERE-luc reporter construct. Summary of fold induction of ERE-luciferase construct observed in transient transfection experiments with ER $\beta 1$ constructs. hER $\alpha$ is shown for comparison. Results are the mean of at least 3 experiments

\begin{tabular}{|c|c|c|c|c|c|c|c|c|}
\hline & \multicolumn{2}{|c|}{ Human } & \multicolumn{2}{|c|}{ Macaque } & \multicolumn{2}{|c|}{ Marmoset } & \multicolumn{2}{|l|}{ hER $\alpha$} \\
\hline & $10^{-7}$ & $10^{-6}$ & $10^{-7}$ & $10^{-6}$ & $10^{-7}$ & $10^{-6}$ & $10^{-7}$ & $10^{-6}$ \\
\hline \multicolumn{9}{|l|}{ Ligand } \\
\hline Oestradiol & $11 \cdot 7$ & $15 \cdot 3$ & $12 \cdot 1$ & $14 \cdot 0$ & $17 \cdot 1$ & $18 \cdot 9$ & $59 \cdot 4$ & $68 \cdot 8$ \\
\hline Adiol & $5 \cdot 4$ & $10 \cdot 4$ & $12 \cdot 2$ & $19 \cdot 1$ & 5.5 & $22 \cdot 3$ & $67 \cdot 6$ & $415 \cdot 8$ \\
\hline Genistein & 4.9 & $7 \cdot 9$ & $2 \cdot 8$ & $5 \cdot 3$ & $4 \cdot 8$ & $7 \cdot 3$ & $3 \cdot 7$ & 3.9 \\
\hline PPT & $1 \cdot 2$ & 1.4 & $7 \cdot 1$ & 14.4 & $1 \cdot 2$ & $6 \cdot 4$ & $169 \cdot 1$ & $176 \cdot 2$ \\
\hline DPN & $7 \cdot \overline{8}$ & $9 \cdot 6$ & $9 \cdot 1$ & $11 \cdot 7$ & $20 \cdot 1$ & $27 \cdot 5$ & $5 \cdot 3$ & $66 \cdot 3$ \\
\hline
\end{tabular}

of the mutant receptor to agonists and antagonists. Both leucine and methionine are hydrophobic and this substitution may therefore have a minimal impact on the orientation of helix 12 following ligand binding. It is notable that the marmoset ER $\beta 1$ was able to induce transcription of the ERE-luciferase reporter gene in vitro and we therefore assume a receptor-ligand dimer was formed and was able to recruit endogenous co-activator proteins efficiently.

Crystallographic studies have identified the amino acids within the ligand binding domains of $\operatorname{ER} \alpha$ and $\operatorname{ER} \beta$ that line the binding cavity and contribute to ligand-specific binding (Brzozowski et al. 1997, Tanenbaum et al. 1998, Pike et al. 1999). These are located in helices 3, 6, 8, 11 and 12 (Pike et al. 1999). Comparison of the ER $\beta 1$ protein sequences from human, macaque and marmoset revealed strong sequence homology and although some amino acids within the ligand binding domain were changed, most of these were not amino acids which interact directly with ligand. In several cases the amino acid encoded by the primate sequence was changed from that seen in the human sequence to the amino acid found in rat or mouse ER $\beta$. Examples of this type of change in the macaque are V239, S243, T252, V341, N520 and in the marmoset S261, L325, V341, E421. Of more interest are changes that either result in substitution of an amino acid to one identical to hER $\alpha$ and/or a change in an amino acid which is conserved between hER $\alpha$ and hER $\beta$ (Pike et al. 1999). For example, in the macaque, the amino acid at position 478 is a serine, in $h E R \beta$ an asparagine is present in this position but hER $\alpha$ has a serine (527). However, this substitution appears unlikely to explain why macaque $\operatorname{ER} \beta 1$ was activated by the ER $\alpha$ selective ligand PPT slightly more efficiently than hER $\beta 1$, as both rat (Pike et al. 1999) and marmoset ER $\beta 1$ have a serine in this position and in the present study marmoset ER $\beta 1$ did not induce reporter gene activity in the presence of PPT any more efficiently than did hER $\beta 1$. Also of interest is the observation that in the marmoset a leucine is present at position 336 (changed from methionine in hER $\beta 1$ ); the equivalent amino acid in hER $\alpha$ is L384. In hER $\alpha$ L384 is one of the amino acids implicated in determining the ligand binding specificity of the ligand binding pocket (Tanenbaum et al. 1998) but more detailed analysis would be needed to determine whether this affects the ability of marmoset ER $\beta$ to bind ligands.

Two of the amino acid substitutions in the marmoset ER $\beta 1$ sequence are of particular note when considering ligand interactions. Both changes result in substitution of a valine (V376, V404) in place of an isoleucine which is conserved in hER $\alpha$, hER $\beta$, rat $\operatorname{ER} \beta$ and macaque $\operatorname{ER} \beta$ (Pike et al. 1999). Although both isoleucine and valine are classed as hydrophobic amino acids, valine has a shorter side chain than isoleucine. In $h E R \alpha$ isoleucine 424 (equivalent to I376 in hER $\beta$ ) has been implicated in contributing to the hydrophobic binding site of the receptors (Brzozowski et al. 1997). Studies examining binding of genistein to hER $\beta$ concluded that I376 was one of those making contact with the bound ligand (Pike et al. 1999). In the current series of transient transfections maximal fold activation of the $3 \times$ vitellogenin ERE containing reporter by marmoset ER $\beta 1$ in the presence of selected ligands was as good (e.g. with genistein, oestradiol) or better (e.g. Adiol, DPN) than the equivalent result obtained with $\mathrm{hER} \beta 1$, 

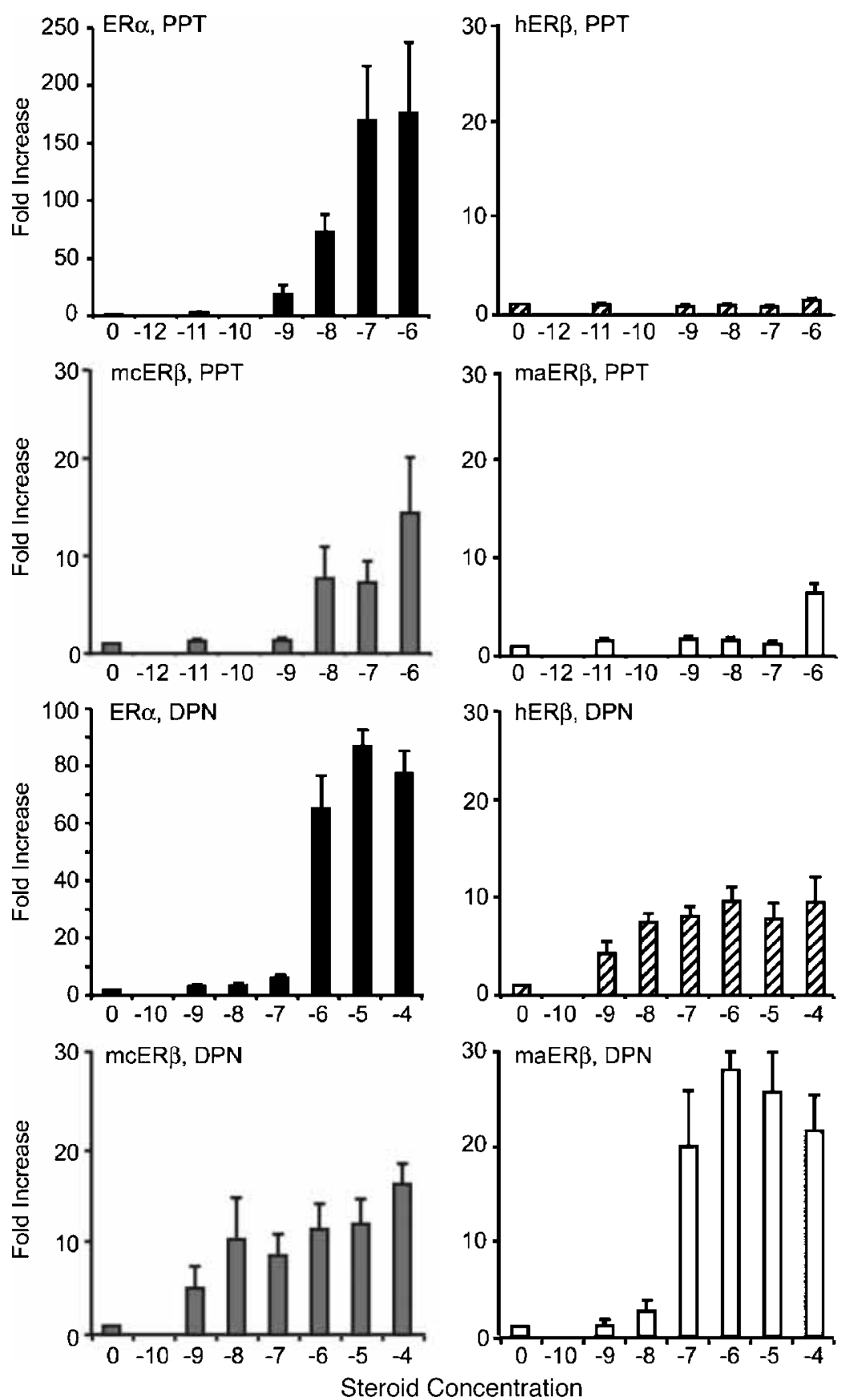

Figure 6 Activation of ER $\beta 1$ from human, macaque and marmoset following incubation with PPT or DPN. Upper panels, PPT $\left(10^{-12}\right.$ to $10^{-6} \mathrm{M}$ ); lower panels, DPN $10^{-10}$ to $10^{-4} \mathrm{M}$. Cells were transfected with plasmids containing hER $\alpha$ (control) or ER $\beta 1$ from human (hER $\beta$ ), macaque $(\mathrm{mcER} \beta)$ and marmoset $(\operatorname{maER} \beta)$. Note that PPT is a potent activator of $E R \alpha$-induced reporter gene expression but does not activate ER $\beta 1$ protein from human or marmoset. DPN is marketed as an ER $\beta 1$ selective agonist but at concentrations of $10^{-6} \mathrm{M}$ or greater it acted as an $\mathrm{ER} \alpha$ agonist. 


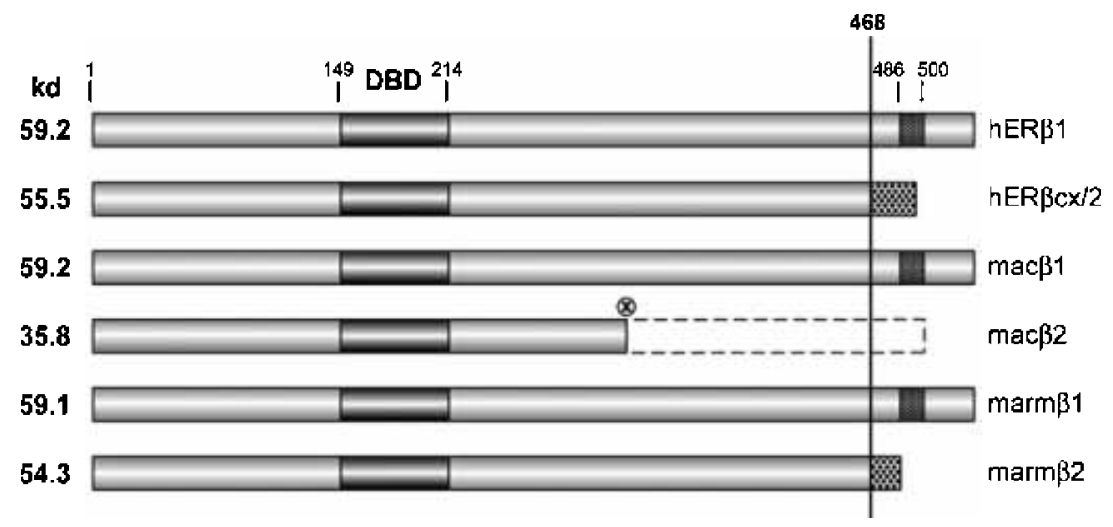

Figure 7 Summary of the structure of the ER $\beta 1$ and ER $\beta 2$ proteins identified in human, stump-tailed macaque and common marmoset. Note that ER $\beta 1$ proteins in all 3 species contain a functional AF-2 domain (486-500 in human) whereas this is absent from the full length ER $\beta 2$ proteins (human, marmoset). The cDNA for the macaque contained a fragment of intronic sequence which included a stop codon (x), resulting in the synthesis of a truncated protein. Sizes given are those equivalent to the protein synthesised from the first ATG in the open reading frame.

suggesting that this substitution might have influenced receptor activity. However, further studies would be required before we can be sure that the ligand binding pocket has been changed in the marmoset protein.

In conclusion, we have cloned and sequenced ER $\beta$ cDNAs from both Old World (M. arctoides) and New World (C. jacchus jacchus) primates and have demonstrated not only that the ER $\beta 1$ sequences are largely conserved but also that the alternative splicing of the eighth exon of the ER $\beta 2$ gene occurs in these species as well as in the human.

\section{References}

Anon 1999 A unified nomenclature system for the nuclear receptor superfamily. Cell 97 161-163.

Barkhem T, Carlsson B, Nilsson Y, Enmark E, Gustafsson J \& Nilsson S 1998 Differential response of estrogen receptor alpha and estrogen receptor beta to partial estrogen receptor agonists/antagonists. Molecular Pharmacology 54 105-112.

Brzozowski AM, Pike ACW, Dauter Z, Hubbard RE, Bonn T, Engstrom O, Ohman L, Greene GL, Gustafsson J-A \& Carlquist M 1997 Molecular basis of agonism and antagonism in the estrogen receptor. Nature $\mathbf{3 8 9} 753-758$.

Chu S \& Fuller PJ 1997 Identification of a splice variant of the rat estrogen receptor beta gene. Molecular and Cellular Endocrinology 132 195-199.

Chu S, Mamers M, Burger HG \& Fuller PJ 2000 Estrogen receptor isoform gene expression in ovarian stromal and epithelial tumors. Fournal of Clinical Endocrinology and Metabolism $\mathbf{8 5}$ $1200-1205$.
Cowley SM, Hoare S, Mosselman S \& Parker SG 1997 Estrogen receptors alpha and beta form heterodimers on DNA. Fournal of Biological Chemistry 272 19858-19862.

Critchley HOD, Henderson TA, Kelly RW, Scobie GS, Evans LR, Groome NP \& Saunders PTK 2002 Wild type estrogen receptor, $\mathrm{ER} \beta 1$ and the splice variant $(\mathrm{ER} \beta \mathrm{cx} / \beta 2)$ are both expressed throughout the normal menstrual cycle. Fournal of Clinical Endocrinology and Metabolism 87 5265-5273.

Enmark E, Pelto-Huikko M, Grandien K, Lagercrantz S, Lagercrantz J, Fried G, Nordenskjold M \& Gustafsson J-A 1997 Human estrogen receptor $\beta$-gene structure, chromosomal localization, and expression pattern. Fournal of Clinical Endocrinology and Metabolism 82 4258-4265.

Green S, Walter P, Kumar V, Krust A, Bornert J-M, Argos P \& Chambon P 1986 Human oestrogen receptor cDNA: sequence, expression and homology to v-erb-A. Nature 320 134-139.

Hall JM \& McDonnell DP 1999 The estrogen receptor $\beta$-isoform $(\mathrm{ER} \beta)$ of the human estrogen receptor modulates ER $\alpha$ transcriptional activity and is a key regulator of the cellular response to estrogens and antiestrogens. Endocrinology 140 $5566-5578$.

Hall MJ \& Korach KS 2002 Analysis of the molecular mechanisms of human estrogen receptors $\alpha$ and $\beta$ reveals differential specificity in target promoter regulation by xenoestrogens. Fournal of Biological Chemistry 277 44455-44461.

Inoue S, Ogawa S, Horie K, Hoshino S, Goto W, Hosoi T, Tsutsumi O, Muramatsu M \& Ouchi Y 2000 An estrogen receptor beta isoform that lacks exon 5 has dominant negative activity on both ER $\alpha$ and ER $\beta$. Biochemical and Biophysical Research Communications 279 814-819.

Kelley ST \& Thackray VG 1999 Phylogenetic analyses reveal ancient duplication of estrogen receptor isoforms. Foumal of Molecular Evolution 49 609-614.

Kuiper GGJM, Enmark E, Pelto-Huikko M, Nilsson S \& Gustafsson J-A 1996 Cloning of a novel estrogen receptor expressed in rat prostate. PNAS 93 5925-5930.

Kuiper GGJM, Carlsson B, Grandien K, Enmark E, Haggblad J, Nilsson S \& Gustafsson J-A 1997 Comparison of the ligand binding specificity and transcript tissue distribution of estrogen 
receptors alpha and beta. Endocrinology 138 863-870.

Lees JA, Fawell SE, White R \& Parker MG 1990 A 22-amino acid peptide restores DNA-binding activity to dimerization-defective mutants of the estrogen receptor. Molecular and Cellular Biology 10 $5529-5531$.

Lu B, Leygue E, Dotzlaw H, Murphy LC \& Watson PH 1998 Estrogen receptor- $\beta$ mRNA variants in human and murine tissues. Molecular and Cellular Endocrinology 138 199-203.

Lu B, Leygue E, Dotzlaw H, Murphy LJ \& Murphy LC 2000 Functional characteristics of a novel murine estrogen receptor-beta isoform, estrogen receptor-beta 2. Fournal of Molecular Endocrinology 25 229-242.

Mahfoudi A, Roulet E, Dauvois S, Parker MG \& Wahli W 1995 Specific mutations in the estrogen receptor change the properties of antiestrogens to full agonists. Proceedings of the National Academy of Sciences of the USA 92 4206-4210.

Meyers MJ, Sun J, Carlson KE, Marriner GA, Katzenellenbogen BS \& Katzenellenbogen JA 2001 Estrogen receptor-beta potency-selective ligands: structure-activity relationship studies of diarylpropionitriles and their acetylene and polar analogues. Fournal of Medicinal Chemistry 44 4230-4251.

Millar MR, Sharpe RM, Weinbauer GF, Fraser HM \& Saunders PTK 2000 Marmoset spermatogenesis: organisational similarities to the human. International Fournal of Andrology 23 266-277.

Moore JT, McKee DD, Slentz-Kesler K, Moore LB, Jones SA, Horne EL, Su JL, Kliewer SA, Lehmann JM \& Willson TM 1998 Cloning and characterisation of human estrogen receptor beta isoforms. Biochemical and Biophysical Research Communications $\mathbf{2 4 7}$ $75-78$.

Mosselman S, Polman J \& Dijkema R 1996 ERbeta: identification and characterization of a novel human estrogen receptor. FEBS Letters 392 49-53.

Nie R, Zhou Q Jassim E, Saunders PTK \& Hess RA 2002 Differential expression of estrogen receptors $\alpha$ and $\beta$ in reproductive tracts of the adult male dog and cat. Biology of Reproduction 66 1161-1168.

Nilsson S, Makela S, Treuter E, Tujague M, Thomsen J, Andersson G, Enmark E, Pettersson K, Warner M \& Gustafsson JA 2001 Mechanisms of estrogen action. Physiological Reviewes $\mathbf{8 1}$ $1535-1565$

Ogawa S, Inoue S, Watanabe T, Hiroi H, Orimo A, Hosoi T, Ouchi Y \& Muramatsu M $1998 a$ The complete primary structure of human estrogen receptor beta (hER beta) and its heterodimerization with ER alpha in vivo and in vitro. Biochemical and Biophysical Research Communications 243 122-126.

Ogawa S, Inoue S, Watanabe T, Orimo A, Hosoi T, Ouchi Y \& Muramatsu M $1998 b$ Molecular cloning and characterization of human estrogen receptor $\beta c x$ : a potential inhibitor of estrogen action in human. Nucleic Acids Research 26 3505-3512.

Peng B, Lu B, Leygue E \& Murphy LG 2003 Putative functional characteristics of human estrogen receptor-beta isoforms. Fournal of Molecular Endocrinology 30 13-29.

Petersen DN, Tkalcevic GT, Koza-Taylor PH, Turi TG \& Brown TA 1998 Identification of estrogen receptor $\beta 2$, a functional variant of estrogen receptor $\beta$ expressed in normal rat tissues. Endocrinology 139 1082-1092.

Pettersson K, Grandien K, Kuiper GGJM \& Gustafsson J-A 1997 Mouse estrogen receptor $\beta$ forms estrogen receptor response element-binding heterodimers with estrogen receptor $\alpha$. Molecular Endocrinology 11 1486-1496.

Pike ACW, Brzozowski AM, Hubbard RE, Bonn T, Thorsell A-G, Engstrom O, Ljunggren J, Gustafsson J-A \& Carlquist M 1999 Structure of the ligand-binding domain of oestrogen receptor beta in the presence of a partial agonist and a full antagonist. EMBO fournal 18 4608-4618.

Poola I, Abraham J \& Baldwin K $2002 a$ Identification of ten exon deleted ERbeta mRNAs in human ovary, breast, uterus and bone tissues: alternate splicing pattern of estrogen receptor beta mRNA is distinct from that of estrogen receptor alpha. FEBS Letters $\mathbf{5 1 6}$ 133-138.

Poola I, Abraham J \& Liu A $2002 b$ Estrogen receptor beta splice variant mRNAs are differentially altered during breast carcinogenesis. Foumal of Steroid Biochemistry and Molecular Biology 82 169-179.

Saji S, Omoto Y, Shimizu C, Horiguchi S, Watanabe T, Funata N, Hayash S, Gustafsson JA \& Yoi M 2002 Clinical impact of assay of estrogen receptor beta cx in breast cancer. Breast Cancer 9 303-307.

Saunders PTK 1998 Oestrogen receptor beta (ER $\beta)$. Reviewes of Reproduction 3 164-171.

Saunders PTK, Millar MR, Williams K, Macpherson S, Harkiss D, Anderson RA, Orr B, Groome NP, Scobie G \& Fraser HM 2000 Differential expression of estrogen receptor-alpha and -beta and androgen receptor in the ovaries of marmoset and human. Biology of Reproduction 63 1098-1105.

Saunders PTK, Sharpe RM, Williams K, Macpherson S, Urquhart H, Irvine DS \& Millar MR 2001 Differential expression of oestrogen receptor alpha and beta proteins in the testes and male reproductive system of human and non-human primates. Molecular Human Reproduction 7 227-236.

Saunders PTK, Millar MR, Macpherson S, Irvine DS, Groome NP, Evans LR, Sharpe RM \& Scobie GA 2002a Estrogen receptor beta $(\mathrm{ER} \beta 1)$, and the estrogen receptor beta 2 splice variant $(\mathrm{ER} \beta \mathrm{cx} / 2)$, are expressed in distinct cell populations in the adult human testis. Fournal of Clinical Endocrinology and Metabolism $\mathbf{8 7}$ 2706-2715.

Saunders PTK, Millar MR, Williams K, Macpherson S, Bayne C, O'Sullivan C, Anderson TJ, Groome NP \& Miller WR 2002b Expression of oestrogen receptor beta (ERbetal) protein in human breast cancer biopsies. British Fournal of Cancer 86 250-256.

Scobie GS, Macpherson S, Millar MR, Groome NP, Romana PG \& Saunders PTK 2002 Human estrogen receptors: differential expression of ERalpha and beta and the identification of ERbeta variants. Steroids 67 985-992.

Shiau AK, Barstad D, Loria PM, Cheng L, Kushner PJ, Agard DA \& Greene GL 1998 The structural basis of estrogen receptor/coactivator recognition and the antagonism of this interaction by tamoxifen. Cell 95 927-937.

Speirs V, Adams IP, Walton DS \& Atkin SL 2000 Identification of wild-type and exon 5 deletion variants of estrogen receptor beta in normal human mammary gland. Fournal of Clinical Endocrinology and Metabolism 85 1601-1605.

Stauffer SR, Coletta CJ, Tedesco R, Nishiguchi G, Carlson KE, Sun J, Katzenellenbogen BS \& Katzenellenbogen JA 2000 Pyrazole ligands: structure-affinity/activity relationships and estrogen receptor-alpha-selective agonists. Fournal of Medical Chemistry $\mathbf{4 3}$ $4934-4947$.

Tanenbaum DM, Wang Y, Williams SP \& Sigler PB 1998 Crystallographic comparison of the estrogen and progesterone receptor's ligand binding domains. PNAS 95 5998-6003.

Thornton JW 2001 Evolution of vertebrate steroid receptors from an ancestral estrogen receptor by ligand exploitation and serial genome expansions. PNAS 98 5671-5676.

Thornton JW, Need E \& Crews D 2003 Resurrecting the ancestral steroid receptor: ancient origin of estrogen signaling. Science $\mathbf{3 0 1}$ 1714-1717.

Tremblay GB, Tremblay A, Labrie F \& Giguere V 1999 Dominant activity of activation function (AF-1) and differential stoichiometric requirements for $\mathrm{AF}-1$ and -2 in the estrogen receptor alpha-beta heterodimeric complex. Molecular Cell Biology 19 1919-1927.

Walther N, Lioutas C, Tillmann G \& Ivell R 1999 Cloning of bovine estrogen receptor beta (ERbeta): expression of novel deleted isoforms in reproductive tissues. Molecular and Cellular Endocrinology 152 37-45. 
Weihua Z, Saji S, Makinen S, Cheng G, Jensen EV, Warner M \& Gustafsson J-A 2000 Estrogen receptor (ER) $\beta$, a modulator of $\mathrm{ER} \alpha$ in the uterus. PNAS $975936-5941$.

Wistuba J, Schrod A, Greve B, Hodges JK, Aslam H, Weinbauer GF \& Luetjens CM 2003 Organization of seminiferous epithelium in primates: relationship to spermatogenic efficiency, phylogeny and mating system. Biology of Reproduction $69582-591$.

Zhou Q, Nie R, Prins GS, Saunders PT, Katzenellenbogen BS \& Hess RA 2002 Localization of androgen and estrogen receptors in adult male mouse reproductive tract. Fournal of Andrology $\mathbf{2 3}$ 870-881.

Received 12 December 2003

Accepted 24 March 2004

Made available online as an

Accepted Preprint 30 March 2004 